\title{
Forest Cover and Land Use Change in Ngumburuni Forest Reserve, Rufiji District, Tanzania
}

\author{
Jerome Kimaro (Corresponding author) \\ Tanzania Wildlife Research institute \\ Box 661 Arusha, Tanzania \\ Tel: 255-7872-75538Ｅ-mail: jegaki@hotmail.com \\ Luther Lulandala \\ Sokoine University of Agriculture, Faculty of Forestry \\ Box 3000, Morogoro, Tanzania \\ Tel: 255-754-458-783Ｅ-mail: 1lulandala@yahoo.com
}

Received: April 29, 2013 Accepted: July 9, 2013 Published: December 1, 2013

doi:10.5296/jee.v4i2.4960ＵRL: http://dx.doi.org/10.5296/jee.v4i2.4960

\begin{abstract}
The present study was carried in Ngumburuni Forest Reserve (NFR), Rufiji District, Coast Region, Tanzania to determine the status of forest vegetation cover under the influence of land use intensification in the surrounding environment over the period of 1985 to 2008 . Socio-economic surveys were conducted to gather information pertaining to land use and causes of forest cover changes from three adjacent villages namely: Umwe north, Muyuyu and Mangwi. Landsand TM satellite imagery approach was, also, used to reflect on the forest vegetation cover dynamics over time using satellite images of 1985, 1995 and 2004 years. The results revealed that the major causes of changes in vegetation cover in Ngumburuni forest reserve were the existence of several forest management practices such as cultivation, logging and charcoaling. Similarly, analysis of satellite images confirmed expanding and shrinkage of some vegetation covers within the forest over time. The changes were more pronounced in the period 1995 to 2004 compared to the period 1985 to 1995 . To reduce further degradation of the forest, several measures are suggested in this study.
\end{abstract}

Keywords: Satellite images, Human disturbances, Community, Vegetation cover change 


\section{Introduction}

Recent studies have indicated that between 1970 and 1998, Tanzania had lost approximately 10 million ha of forest vegetation cover through uncontrolled clearing of forests mainly for agriculture and livestock expansion (Hall et al., 2009; URT, 1998).

Both natural and human induced factors play significant roles in bringing changes in vegetation cover and tree biodiversity. According to Mogaka et al., 2001, the sensitivity in the value of the forest goods and services varies greatly in accordance with the scale, intensity, and type of these changes (Clausnitzer, 2003). This could be anything from a slight selective logging of undisturbed natural forest to a total clearance of trees and a subsequent transformation of the previous forest site into non forest uses (Milledge et al., 2007).

The Ngumburuni Forest Reserve (NFR) located in Southern Tanzania, is one of the most biodiversity rich areas in the country that have been reported to face severe human disturbances (Clausnitzer, 2003; REMP, 2003). This forest forms one of the important ecological patches of East African Coastal Forests which are sometimes called forests of "Zanzibar - Inhambane Regional Forest Mosaic" (White, 1983). Several endemic tree species are distributed throughout the range of the forests. Examples are the Dialium holtizii, Bombax rhodognaphalon, Comiphola zanzibarica and the marginally endemic Sterculia appendiculata trees (Burgess, 2005). This situation is also true for near-endemics only with the birds Fischer's Greenbul (Phyllastrephus fischeri), Green Tinkerbird (Pogoniulus simplex), Spotted Ground Trush (Zoothera fischeri) and Tiny Greenbul (Phyllasterphus debilis) having a wide distribution (Burgess \& Clarke, 2000). Vegetation dynamics, defined as changes in stand structure and composition over time, is a major aspect of vegetation ecology (Jackson et al., 2001). Studying appropriate forestry variables and parameters and applying them to specific vegetation layers in a certain sequence can generate invaluable data on the past, present, and even future vegetation structure dynamics (Poynton, 2003; Stibig, 2003).

Despite its ecological, social and cultural significance, management of NFR is still challenging. Detailed scientific information on its utilization patterns and ecological functioning still remain insufficiently researched and documented. It is, therefore, anticipated that the information generated from this study will form a sound basis for effective planning and management of the reserve by the various local and international conservation stakeholders, given the fact that the NFR is within the Rufiji delta ecosystem, one of the Ramsar sites in Tanzania. Likewise, the forest is important wildlife migratory corridor for many large mammals such as elephants and buffalos crossing from the Selous Game Reserve to other forests on the eastern side of the reserve (REMP, 2003).

\section{Materials and Methods}

\subsection{Study Area}

Ngumburuni Forest Reserve is located in Rufiji District, Coast Region, Tanzania, between $7^{0}$ $38^{\prime}$ and $7^{\circ} 48^{\prime} \mathrm{E}, 38^{\circ} 52^{\prime}$ and $39^{\circ} 6^{\prime} \mathrm{S}$. Within the elevation of $200 \mathrm{~m}$ from the mean sea level, the forest covers about 10,000 ha (REMP, 2003). Average annual rainfall varies from 900 
$\mathrm{mm}$ to $1,400 \mathrm{~mm}$, with significant daily, monthly and annual fluctuations; temperatures are ranging between 24 and $31^{\circ} \mathrm{C}$ with an average of $26^{\circ} \mathrm{C}$ (Burgess \& Clarke, 2000). The main economic activities of adjacent communities are agriculture and forest dependent activities such as logging and fuel wood (i.e. firewood and charcoal) production (Semesi, 1990). There are about 484 different tree species in the area, with a high level of plant species endemism (Munishi et al., 2004). Similarly, several species of endemic mammals and birds are found in the coastal forest reserve (Clausnitzer, 2003).

\subsection{Data Collection}

Landsat images of the 1985, 1995 and 2004 years were used to identify and map out land cover features and land cover patterns followed by the identification and interpretation of the subscenes of land cover changes of the study area subjected to a digitized screen using the ArcView software. The land cover/use boundaries were identified, delineated and mapped on the basis of the colour hue, textural and structural values. The area under each land cover/use class was calculated and used for comparison and documentation of the temporal changes. Visual image interpretation was complemented by the ground truthing and socio-economic survey data collected from the field during the survey. GPS was used to mark positions of features like trail roads, wetland areas and most disturbed areas of the forest to generate new information layers that explain the current status of the forest.

The socio-economic data on land use intensification and patterns, forest conservation and forest vegetation dynamics, were collected from the heads of 30 randomly selected households from each of the three random sample villages (i.e. Mangwi, Muyuyu and Umwe) among those closely surrounding the forest reserve, to form a total sample of 90 household heads who were interviewed using structured questionnaires. In addition to the households heads, information was, also, collected from other key informants that included the Chairpersons and Executive Secretaries of the sample villages, Village Environmental Management Committees (VEMCs), representatives of the various social groups such as the village elders, women, youth, businesspersons and NGOs available in the respective villages, various extension staff (e.g. Agriculturists, Foresters, Livestock Officers etc.) at the various levels from the village to the district, using checklists of probe questions. One Participatory Rural Appraisal (PRA) was, similarly, conducted in each sample village in order to get the community overview of the study area.

\subsection{Data Analysis}

GIS analysis was done by using Arc View 1.3 and ERDAS Imagine Software, Version 8.3.1 programs to understand the current status of forest vegetation types and the trend of vegetation cover change. Ground truthing was done to verify and modify land covers described in the preliminary stages of image interpretation.

Socio economic data were analyzed by combination of qualitative and quantitative methods. Qualitative data were analyzed using content analysis (Kajembe, 1994), whereas quantitative data were analyzed with the aid of Statistical Package for Social Sciences (SPSS) version 16 and Excel Spread Sheet 2003. Analyzed data was presented in descriptive statistics, charts 


\section{Macrothink}

and tables.

\section{Results}

\subsection{Major Ecological Units and Land-Use}

We identified five major classes of land use/cover which were dense forests, woodland, open Miombo woodlands combined with grasslands, riverine forests and farmland (Figure 1). A dense forest

cover was consisting of two strata identified as the coastal forests and closed Miombo woodlands.

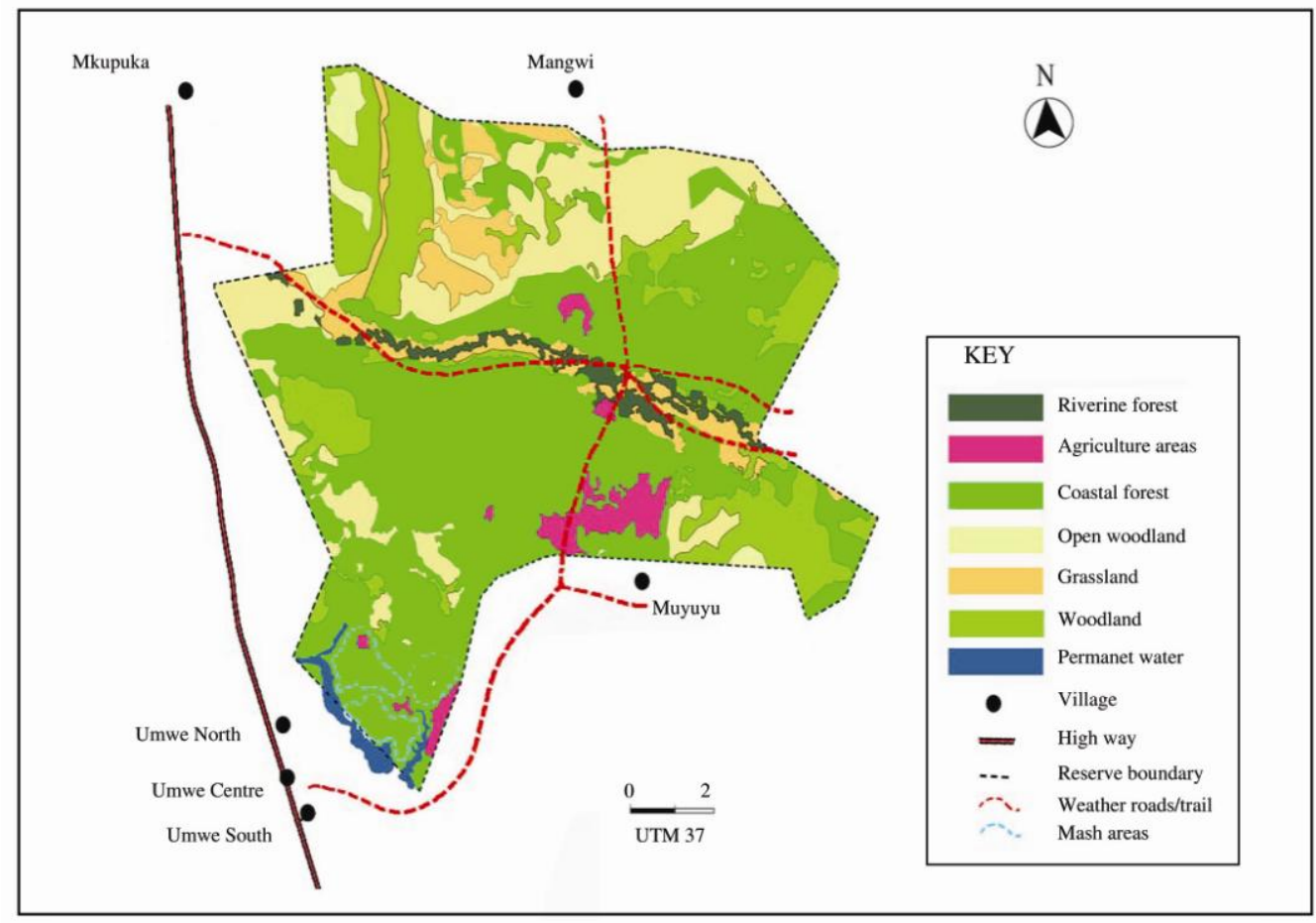

Figure 1. Major ecological units at Ngumburuni Forest Reserve.

The reserve is bisected in the middle by the Ruhoi River, which has high biodiversity value. Several valuable tree species like Mkongo (Afzelia quanzensis), Mnangu (Hymenaea verrucosa), Mdadarika (Newtonia sp.) and Mtanga (Albizia versicolor) were observed during the survey.

The western part of the forest reserve was observed to be the most disturbed by commercial logging, charcoaling and cultivation and several criss-cross roads were present in the forest indicating a high traffic of large lorries were involved in smuggling of logs and charcoal. The central part was characterized by open the woodland with trees of average size, while the southern part of the forest had permanent wetland patches including Lake Umwe. 


\section{$\triangle$ Macrothink}

\subsection{Trend of Vegetation Cover Change}

Vegetation cover was observed to change over time within NFR as presented in Table 1 and Figure 2. There was a steep degradation in the closed coastal Miombo and riverine forest strata into open Miombo woodlands, grasslands and farmlands representing approximately $40 \%, 31 \%$ and $28 \%$ respectively, especially on the north-western fringe of the forest reserve. The change was more drastic during the 1995 to 2004 period as compared to the 1985 to 1995 one. It was further observed that the biodiversity rich strata of NFR (i.e. closed coastal Miombo and riverine forests) which covered a total area of 9092 ha in 1985 had declined to 6630 ha in 2004, reflecting a 27\% deforestation over the 20 years. A more dramatic change involved the expansion of the open woodlands, grasslands and cultivation areas by approximately 500\% between the two assessment periods (i.e. 1985-1995 and 1995 -2004).

Table 1. Forest cover changes by area in Ngumburuni forest reserve

\begin{tabular}{|l|l|l|l|l|l|l|l|}
\hline \multirow{2}{*}{$\begin{array}{l}\text { Vegetation } \\
\text { Stratum }\end{array}$} & \multicolumn{6}{|l|}{ Vegetation cover (ha) } & \multicolumn{2}{l|}{ Vegetation cover changes } \\
\cline { 3 - 9 } & 1985 & 1995 & 2004 & Area (ha) & Proportion (\%) & Area (ha) & Proportion (\%) \\
\cline { 2 - 9 } & 5976 & 5621 & 4290 & -355 & 6 & -1331 & 24 \\
\hline Coastal forest & 2111 & 2006 & 1590 & -105 & 5 & -416 & 21 \\
\hline Closed Miombo woodland & 574 & 1086 & 2595 & 512 & 89 & 1509 & 139 \\
\hline $\begin{array}{l}\text { Open Miombo woodland } \\
\text { and grassland }\end{array}$ & & & & & & & \\
\hline Riverine Forest & 1005 & 850 & 750 & -155 & 15 & -100 & 12 \\
\hline Area of cultivation & 112 & 214 & 525 & 102 & 91 & 311 & 145 \\
\hline
\end{tabular}

A negative sign (-) means decreasing in area size 


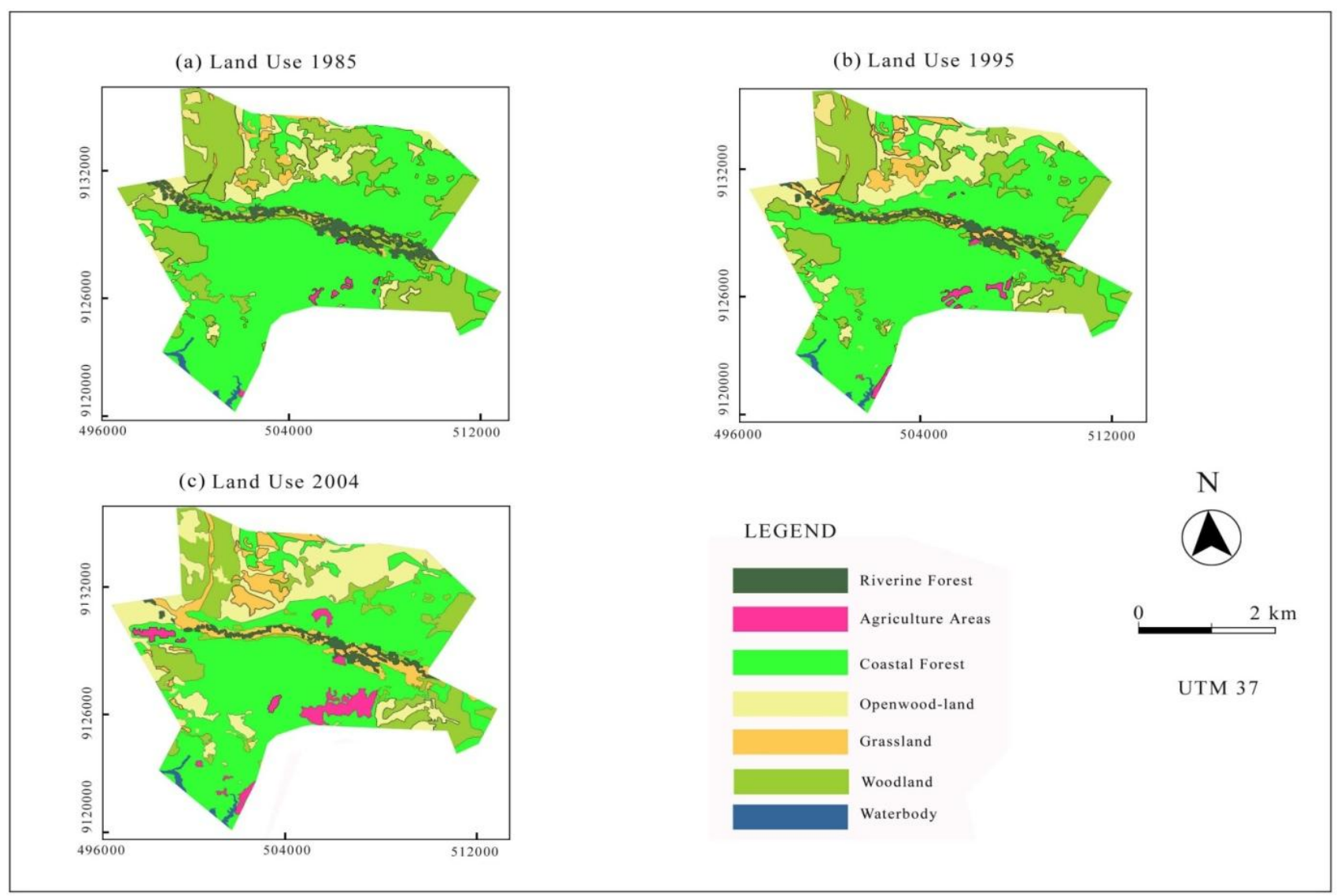

Figure 2. Status of vegetation cover of Ngumburuni Forest Reserve, Rufiji, Tanzania during the three assessment periods of 1985, 1995 and 2004

\subsection{Causes of Forest Cover Change}

Results on the causes of forest disturbance in the NFR are summarized in Tables 23 and Figure 3. During our field survey, we found nearly 50 fresh pit-sawing sites distributed in different locations of the forest. Valuable trees like Muninga (Pterocarpus angolensis) and Mkongo (Afzelia quanzensis) were more targeted for harvesting compared to other species. It was also reported by key informants that small diameter logs, also known as off- cuts, were being traded by the illegal loggers indicating the increasing scarcity of valuable timber from the forest.

Fire was reported as a common feature in almost every activity being undertaken in the forest reserve, such as clearing the bushes for logging, preparing farms, charcoaling, harvesting honey and poaching wild animals. Based on the household surveys, the responses obtained were grouped into three main related drivers of deforestation that included the economic (83\%), institutional (74\%) and demographic (77\%) factors (Table 2). 


\section{Macrothink}

Journal of Environment and Ecology

ISSN 2157-6092

2013, Vol. 4, No. 2

Table 2. Major underlying causes of deforestation in Ngumburuni

Source: own survey, 2005

\begin{tabular}{|l|l|}
\hline Underlying causes & $(\mathrm{n}=90)$ \\
\hline & Mean frequency $(\%)$ \\
\hline Economic factors & 83 \\
\hline Institutional/ Policy factors & 74 \\
\hline Demographic factors & 77 \\
\hline
\end{tabular}

Table 3. Description of activities allowed and not allowed in the Ngumburuni forest reserve

\begin{tabular}{|l|l|l|l|}
\hline Forest uses & $\begin{array}{l}\text { Should be stopped } \\
\text { (highly damaging) }\end{array}$ & Could be sustained & Could be increased \\
\hline Timber & $\mathrm{x}$ & & \\
\hline Charcoal production & $\mathrm{x}$ & & \\
\hline Settlements & $\mathrm{x}$ & & \\
\hline Shifting cultivation & $\mathrm{x}$ & & \\
\hline Fuel wood collection & & $\mathrm{x}$ & $\mathrm{x}$ \\
\hline Beekeeping & & $\mathrm{x}$ & \\
\hline Collecting Wild honey & & & \\
\hline Collecting wild food & & $\mathrm{x}$ & \\
\hline Collecting building poles & & $\mathrm{x}$ & $\mathrm{x}$ (if palms) \\
\hline $\begin{array}{l}\text { Roofing } \\
\text { collection }\end{array}$ & & $\mathrm{x}$ & \\
\hline Weaving & & $\mathrm{x}$ (roots and barks) & \\
\hline Medicine collection & & & \\
\hline Hunting & $\mathrm{x}$ & & $\mathrm{x}$ \\
\hline Tourism & & & \\
\hline source: REMP 2003 & & & \\
\hline
\end{tabular}




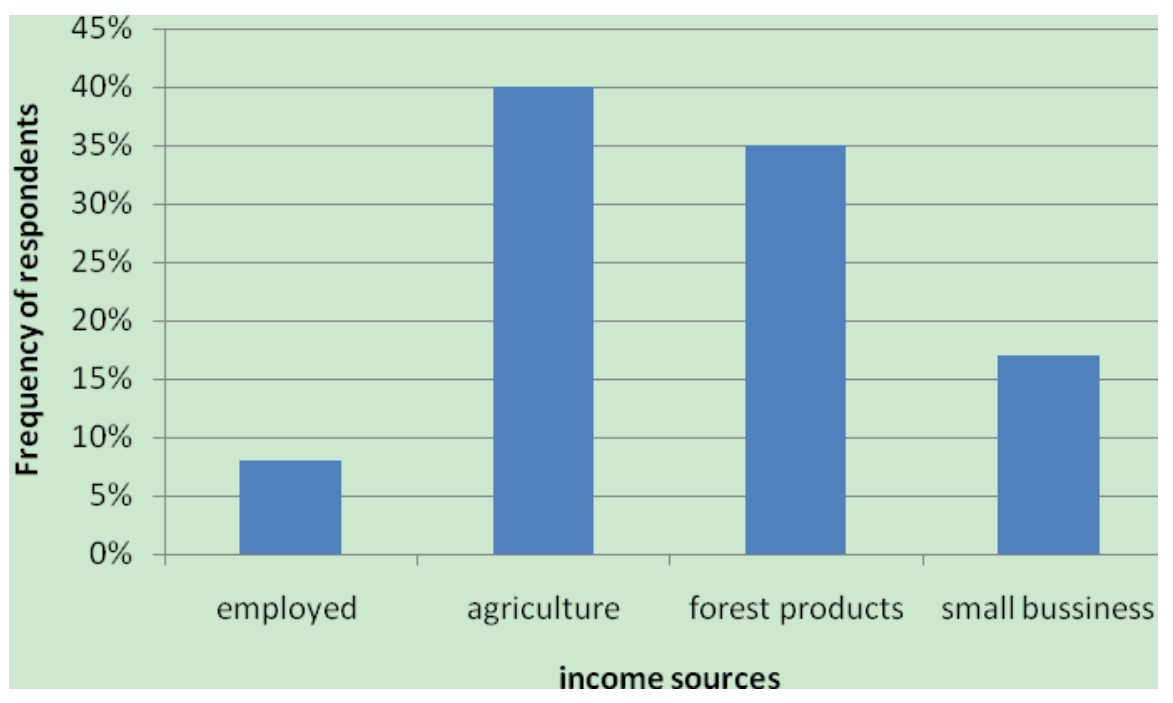

Figure 3. Major income sources among villagers adjacent to Ngumburuni Forest Reserve

\section{Discussion}

Ecological functioning and biodiversity integrity of NFR is decreasing with time due to the loss of valuable tree vegetation cover and increasing of open grasslands and farmlands. This reveals that the forest is facing some serious disturbances especially in the central and northwestern parts of the reserve. The reasons for this are mainly the increasingly growing human population in the surrounding villages, such as Mangwi, and the area's closeness to the Dar es Salaam - Mtwara highway. It has, also, been observed elsewhere that one of the crucial factors in deforestation is human population growth reinforced by various underlying causes such as poverty and unequal access to land (URT, 1998). Similarly (Milledge et al., 2007) urges that there is a strong link between road construction and deforestation whereby the then remote areas are later accessible and create avenues for activities like agriculture, logging and settlements. Due to opening of the forest canopy, lianas are invading the gaps and make it more easily susceptible to secondary disturbances. Clearing of large trees, promotes the grass and other herbaceous vegetation thereby subjecting the forest to become even more prone to fires and excessive biodiversity loss (Cauldwell and Zieger 2002).

The presence of a high water table in the reserve can, also, be a reason for some agricultural encroachments that stretch along the Ikwiriri - Muyuyu road. Many farmers around Ngumburuni Forest Reserve, reported to possess farm plots in the wetland area within the reserve locally known as Njacha. Water availability has been the major factor that determines direction of smallholder farmers' activities (Kangarawe et al., 2005). The main crops grown in this area include rice, cassava and cowpeas.

The drastic change in the forest during the 1995 to 2004 period is associated with infrastructural development in the southern corridor of Tanzania and adoption of global free trade policy. In the first instance, the improvement of the Dar es salaam-Mtwara highway and 
completion of the Mkapa Bridge crossing the Rufiji River (Milledge et al., 2007), increased the accessibility of people to Rufiji District from nearby towns who were looking for business opportunities and cheap fertile land for agriculture and new settlements. Following Tanzania's decision on adoption of the free trade policy in natural resources utilization (Kaale, 2002), colossal quantities of timber, from southern Tanzania including NFR, were exported to Asia and Europe (Songas, 2003). The increase in the market of hardwood from Tanzania, especially to China, has been a lucrative business to everyone who was involved in the business, from felling trees in the forest to transportation. All these changes brought impact to forest resources in Rufiji District. Degradation of NFR is best explained by a multiple of factors and drivers acting synergistically rather than by single-factor causations. However, the major causes of deforestation are human activities rather than natural causes (Majule et al., 2009). During the ground truthing surveys, we met five logging teams in the act but three of them ran away fearing of being caught. We also observed that even the immature trees of some of species, especially Muninga (Pterocarpus angolensis) and Mkongo (Afzelia quanzensis), were being heavily harvested, which was a clear indication that such valuable timber species in the reserve are already overharvested. The recommended tree sizes of Diameter at Breast Height $(\mathrm{DBH})$ of harvesting indigenous trees in Tanzania, vary with groups or individual tree species whereby for Mkongo (Afzelia quanzensis), Myombo (Brachystegia spiciformis) or Mninga (Pterocarpus angolensis), for example, the set lower limit is $60 \mathrm{~cm}$ while Mpangapanga (Millettia stuhlmannii) or Mpingo (Dalbergia melanoxylon), is $40 \mathrm{~cm}$ (Malimbwi 2000). The tree stems with the DBHs below such limits, are considered immature trees.

Forest based activities like logging; charcoaling and shifting cultivation are known to be major sources of income generation for the adjacent communities. NFR has, for many years, been known as one of the timber extraction hotspots in Southern Tanzania (Milledge, 2007). Apart from the commercial exports of hardwood timber, it was reported that the shooting prices of industrial building materials, had forced local communities to rely on the forest based raw materials as dependable and readily available alternatives (URT, 2000). An average-sized rural house, for instance, would roughly require 300 building poles which last between three and five years (Burgess and Clarke 2000). Indeed, the poles are not only cut from among the shrub species but, also, from among the regenerating stems of timber tree species (Burgess and Clarke 2000). Communities around NFR prefer tree species that are durable, straight and insect resistant such as Dombeya rotundifolia, Acacia nigrescens, Spirostachys africana, Pteleopsis myrtifolia, Dalbergia melanoxylon, Markhamia obstusifolia and Casusrinas livingistonei.

Furthermore, low household income among villagers was realized to enhance charcoaling activities. As responded by key informants, the majority of villagers earn less than US \$ 25 per month. This amount is not sufficient to meet the necessary household livelihood demands, such as food, clothes, kerosene etc. These findings directly compare with those reported by (Monela et al., 1993), who observed that, the number of people seeking for income generation and employment opportunities through charcoal production was increasing rapidly, consequently increasing pressure on natural woodlands. The high level of charcoal 
production in Rufiji District is heavily influenced by the high demand for domestic energy from nearby population centres like the city of Dar es Salaam, where $65 \%$ of households use charcoal as their main source of cooking energy (Malimbwi et al., 2005).

Likewise, agricultural practices especially shifting cultivation, involve clearing parts of the forest, collecting smaller trees, unused branches, litter and grass into small heaps and burn to form ash to fertilize the soil (Mertz, 2002). As a subsistence strategy, shifting cultivation has not been popular with many government and international agencies (Sunderlin, 2000). As reported by (Chidumayo, 1987), shifting cultivation has been a serious environmental problem in the Miombo woodlands where the crops are grown in small ash gardens locally known as Chitemene. Likewise Gadgil (1992), emphasized that shifting cultivation, to a large extent, results into large-scale deforestation, soil and nutrient loss, and invasion by weeds. Although it did not form part of the present study, the role of women in traditional management practices has increasingly been appreciated globally as a strong incentive for biodiversity conservation. This, therefore, could provide a strong incentive for further future resources monitory studies and stepped up conservation strategies of this significant biodiversity storehouse. Consented linkage with the awareness creation and promotion for scaling up Agroforestry practices among the communities of the surrounding villages (Lulandala, 2012) could, perhaps, form the most effective parallel management strategy for ensured sustainable conservation of NFR.

\section{Implications for Conservation}

The influence of human activities within forest areas is globally recognized as the major threat to ecological functioning and biodiversity integrity in many ecosystems. This leads to the long term deterioration of the forest values and loss of ecosystem services which are, also, important to livelihoods of the adjacent local communities. Biodiversity rich areas like NFR can offer various competitive options that local communities can exploit to enhance resilience of their livelihoods rather than continue with the direct dependence on the forest resources. This consideration should be a concern to all conservation stakeholders especially in this era in which the management of climate change impacts has become more complex. Based on this study, therefore, the following general recommendations are made:

- Introduction of conservation awareness and promotion of green-technologies that will empower local participation in sustainable forest management

- Promotion of micro-credit services and diversification of income generation activities to reduce dependence on forest resources for subsistence

- Enforcing laws and regulations guiding the appropriate use of forest resources among the wide range of stakeholders

- Further monitory studies are needed for NFR in order to create a better understand of its ecological functioning as influenced by the existing socio-economic interactions.

\section{Acknowledgements}

Authors are gratefully acknowledging the support of individuals and organizations that 
devoted their support in preparation of this manuscript. Special thank to chief editor and reviewers for their constructive criticisms which helped to shaping this paper.

\section{References}

Burgess, N., \& Clarke, P. (2000). Coastal Forest of Eastern Africa. Gland, Switzerland: IUCN. p.443.

Burgess, N. (2005). Major gaps in the distribution of protected areas for threatened and narrow range afrotropical plants. Biodiversity and Conservation, 18(8), 1877-1894. http://dx.doi.org/10.1007/s10531-004-1299-2

Cauldwell, A. E., \& Zieger, U. (2002). A reassessment of the fire-tolerance of some miombo woody species in the Central Province, Zambia. African Journal of Ecology, 38(2), 138-146. http://dx.doi.org/10.1046/j.1365-2028.2000.00232.x

Chidumayo, E. (1987). Inventory of Wood Used in Charcoal Production in Zambia Report for Biodiversity Support Program, 35-52.

Clausnitzer, V. (2003). Dragonflies of Rufiji District. p. 154.

Gadgil, M.(1992). Conserving biodiversity as if people matter: A case stuy from India. Ambio Journal, 21(10), 226-270.

Hall, J., Burgess, N. D., Lovett, J., Mbilinyi, B., \& Gereau, R. E. (2009). Conservation implications of deforestation across an elevational gradient in the Eastern Arc Mountains, Tanzania. Biological Conservation, 2510-2521. http://dx.doi.org/10.1016/j.biocon.2009.05.028

Jackson, T., Begg, K., \& Parkinson, S. (2001). Flexibility in Climate Policy -making the Kyoto mechanism work. Earthscan: London, p. 236.

Kaale, B. K., Ramadhani, H. K., Kimaryo, B. T., Maro, R. S., \& Abdi, H. (2002). Participatory Forest Resource Assessment. Misitu Yetu Project. CARE Dar es salaam Tanzania.

Kajembe, G. C. (1994). Indiginous management systems as a basic for community forestry in Tanzania. A case study of Dodoma urban and Lushoto districts, in Tropical Resources Management Paper. Wageningen Agricultural University: Netherlands, P. 194.

Kangalawe, R. M., Majule, A. E., \& Shishira, E. K. (2005). An Analysis of Land Use Dynamics and Land Degradation Processes in the Great Rift Valley, Central Tanzania: A Case of Iramba District". OSSREA.

LLC. (2004). "Illegal” Loging and Global Wood Markerts. Seneca Creek Associates, LLC and Wood Resources International, LLC, US, P. 112.

Lulandala L. L. L. (2012). Development of guidelines to put Agroforestry high on the policy agenda and guide decision makers at the national level. A consultancy report, Sustainable Forest Management in a Changing Climate (GCP/GLO/194/MUL), Forestry Department, 
FAO, Rome, p19.

Majule, A. E., Liwenga, E. T., Kangalawe, R. Y. M., \& Yanda, P. Z. (2009). Natural Resource Contribution to Community Livelihoods. Experience from Selected case Studies in Tanzania. Dar es Salaam: Dar es Salaam University Press Ltd, P. 224.

Malimbwi, R. E., Zahabu, Misana S, Monela, G. C., Jambiya, G. C., \& B, M. (2005). Charcoal supplying potential of the miombo woodlands: the case of Kitulangalo Area, Tanzania. Journal of Tropical Forest Science, 17(2), 197-210.

Malimbwi, R. E. (2000). An Inventory Report of the Principle Timber Resources of the Miombo and Riverine Woodlands and Forests of Rufiji District, in Technical Report No.12. REMP, Utete, Tanzania, P. 134.

Mertz, O. (2002). 'The Relationship between Length of the Fallow and Crop Yields in Shifting Cultivation: A Rethinking'. Agroforestry Systems, 55, 149-159. http://dx.doi.org/10.1023/A:1020507631848

Milledge, S. A. H., Gelvas, I. K., \& Ahrends, A. (2007). Forestry, Governance and National Development: Lessons Learned from a Logging Boom in Southern Tanzania. . Dar es Salaam, Tanzania: TRAFFIC East/Southern Africa / Tanzania Development Partners Group / Ministry of Natural Resources of Tourism.

Mogaka, H., Simons, G., Turpie, J., Emerton, L., \& Karanja, F. (2001). Economic Aspects of Community Involvement in Sustainable Forest Management in Eastern and Southern Africa. 2001, IUCN. p. 151.

Monela, G. C., O'Kting'ati, A., \& Kiwele, P.M. (1993). Socio-economic aspects of charcoal consumption and environmental consequences along the Dar es Salaam-Morogoro highway,

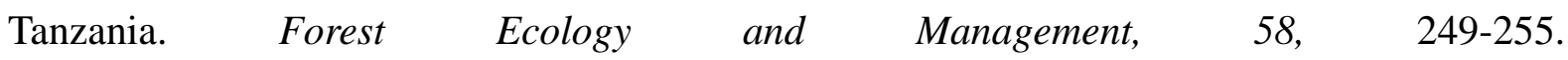
http://dx.doi.org/10.1016/0378-1127(93)90148-G

Moyo, C. L., \& Kowero, G. S. (1986). Some Observations on Sawn Hardwood Exports from Tanzania. Forest Ecology and Management, 18, 153-160. http://dx.doi.org/10.1016/0378-1127(87)90141-1

Munishi, P. K. T., Shear, T. H., Wentworth, T., Temu, R. P. C., \& Maliondo, S. M. (2004). Sparse distribution of pattern of some plants species in two afromontane rain forests of Eastern Arc Mountains of Tanzania. Tanzania Journal of Forestry and Nature Conservation, 75, 74-90.

Poynton, J. C. (2003), Altitudinal species turnover in southern Tanzania shown by anurans: some zoogeographical considerations. Journal of Systematics and Biodiversity, 1(1), 117-126. http://dx.doi.org/10.1017/S1477200002001019

REMP. (2003). Report on Strategy for Assessment of the Woody Vegetation of the Rufiji District. Rufiji, Tanzania

Semesi, A. (1990). Management Plan for the Mangrove Ecosystem of Mainland Tanzania. 


\section{Macrothink}

Volumes 1-10. Ministry of Tourism, Natural Resources and Environment, Forest and Beekeeping Division, Dar es Salaam.

Songas (2003). Songo Songo Gas to Electricity Project, in Environmental Studies. Final Report. SONGAS ltd: Dar es Salaam, Tanzania, P. 66.

Stibig, J. (2003). Forest cover of insular Southeast Asia mapped from recent satellite images of coarse spatial resolution. Ambio, 32 (7), 469-475.

Sunderlin, W. D., Ndoye, H., Bikie, N., Laporte, B., Mertens, \& Pokam, J. (2000). 'Economic Crisis, Small-scale Agriculture, and Forest Change in Southern Cameroon. Environmental Conservation, 27(3), 284-290. http://dx.doi.org/10.1017/S0376892900000321

United Republic of Tanzania .(2000). Dar es Salaam, United Republic of Tanzania. The Status of Ecosystem Conservation and Management in Tanzania and Vision for the Future. Forestry and Beekeeping Division, Dar es salaam, P. 96.

United Republic of Tanzania, The National Forest Policy. (1998). Ministry of Natural Resources and Tourism, Forest and Beekeeping Division: Dar es Salaam. p. 69.

White, F. (1983). The Vegetation of Africa. Paris: UNESCO. 